\title{
ANALISIS RISIKO PRODUKSI USAHATANI PADI ORGANIK DI DESA ROWOSARI KECAMATAN SUMBERJAMBE KABUPATEN JEMBER
}

\author{
Julita Hasanah ${ }^{1}$, Muhammad Rondhi ${ }^{2}$, dan Triana Dewi Hapsari ${ }^{3}$ \\ 1)Program Sarjana Agribisnis, Fakultas Pertanian, Universitas Jember \\ 2,3)Program Studi Agribisnis, Fakultas Pertanian, Universitas Jember \\ e-mail: 2)rondhi_mp@yahoo.co.id
}

\begin{abstract}
Government began to apply the concept of organic farming in order to maintain the sustainability of agriculture. Organic farming is applied to the organic rice farming of Jember Regency. This kind of farming have some risks. The prominent risk in organic rice farming is production. Research conducted at rowosari village aims to know: (1) The amount of production risk overall; (2) The amount of production risk that seen from the length of application organic farming and land area. The location of research in Rowosari, Sumbejambe which was determined intentionally (Purposive Method). The sampling method was total sampling method. The data that used in study were primary and secondary data. The analyze method used was standard deviation $(V)$ and coefficient of variation $(C V)$. The results of the study showed that: (1) Overall risk of production of organic rice farming in Rowosari Village amounted to $468.25 \mathrm{~kg}$ or $10.1 \%$ of the average production: (2) The risk of production of organic rice farming in Rowosari Village are based on the land area small $(0.5 \mathrm{Ha})$, medium $(0.5-2 \mathrm{Ha})$ and large $(>2 \mathrm{Ha})$ respectively $17.6 \%, 6.3 \%$ and $1.3 \%$ of the average production. The risk of production of organic rice farming in Rowosari Village is based on the period of implementation from 2015 and 2012, respectively $12.1 \%$ and $7.8 \%$ of the average production. It showed that the period of organic farming implementation will influence the amount of risk production.
\end{abstract}

Keywords: farming, rice organic, risk production

\section{PENDAHULUAN}

Pembangunan pertanian perlu terus dikembangkan dan diarahkan menuju tercapainya pertanian yang tangguh (Sudrajat, 1994). Menurut Mubyarto (1994), usaha untuk meningkatkan produksi pertanian sebagai realisasi dari pembangunan pertanian ditempuh dengan cara ekstensifikasi, intensifikasi, dan diversifikasi.

Salah satu bentuk intensifikasi pertanian di Indonesia adalah Revolusi hijau. Revolusi hijau di Indonesia merupakan sistem pertanian yang terbukti mampu meningkatkan pertumbuhan ekonomi secara global, khususnya di bidang pertanian (Ricky, 2012). Pelaksanaan program intensifikasi pertanian seiring berjalannya waktu ternyata tidak sesuai dengan yang diharapkan. Banyak penggunaan input usahatani yang tidak memperhatikan keseimbangan ekosistem, walaupun sebenarnya tujuan utama penggunaan input tersebut dimaksudkan supaya memberikan pening- katan produksi dalam usahatani dan nantinya akan memperkuat sektor pertanian sebagai salah satu sektor pembangunan. Adanya dampak buruk intensifikasi pertanian tersebut memberi pelajaran untuk mengubah orientasi pembangunan ke arah pembangunan pertanian berkelanjutan (Saptana dan Ashari, 2007).

Salah satu bentuk pertanian berkelanjutan yang diterapkan di Indonesia adalah pertanian organik. Menurut Hakim et al. (2014), pertanian organik merupakan suatu sistem pertanian yang didesain dan dikelola sedemikian rupa sehingga mampu menciptakan produktivitas yang berkelanjutan. Perkembangan pertanian organik di Indonesia di mulai pada awal 1980an yang ditandai dengan bertambahnya luas lahan pertanian organik, dan jumlah produsen organik Indonesia dari tahun ke tahun.

Berdasarkan data Statistik Pertanian Organik Indonesia (SPOI) yang di terbitkan oleh Aliansi Organis Indonesia (AOI) tahun 
2013, diketahui bahwa luas total area pertanian organik di Indonesia dari tahun ke tahun masih fluktuatif. Luas lahan organik di Indonesia mengalami penurunan pada tahun 2011 dan 2012 dengan nilai sebesar 13,25\% dan 31,07\%. Penurunan luas lahan organik justu terjadi setelah adanya program "Go Organik" yang dilaksanakan oleh Departemen Pertanian.

Pertanian organik diterapkan pada subsektor tanaman pangan, salah satunya diterapkan pada komoditas padi. Pelaksanaan pertanian organik sebagai wujud pertanian berkelanjutan telah diterapkan di beberapa daerah. Salah satu daerah yang menerapkan pertanian padi organik adalah Desa Rowosari Kecamatan Sumberjambe Kabupaten Jember.

Konversi lahan pertanian konvensional menjadi lahan pertanian organik merupakan proses yang harus dilewati oleh petani. Menurut Hanson et al. (2004), Petani organik menanggung risiko spesial selama masa konversi dari pertanian konvensional menjadi pertanian organik. Usahatani padi organik yang berasal dari lahan konvensional (lahan yang menggunakan asupan kimia sintetis) memerlukan masa peralihan.

Peralihan dari pertanian yang dikelola secara konvensional ke pertanian organik seharusnya tidak hanya memperbaiki ekosistem lahan, namun juga menjamin kelangsungan hidup secara ekonomi lahan tersebut. Akan tetapi sebelum mencapai hal tersebut dalam masa transisi muncul dampak terhadap produksi yang dihasilkan, yaitu penurunan produksi antara $10-50 \%$ dari produksi padi konvensional. Adanya hal tersebut memicu timbulnya risiko yang harus dihadapi oleh petani dalam penerapan budidaya padi organik (Asbullah, 2017).

Usaha dalam bidang pertanian terdapat beberapa hal yang dapat memicu munculnya risiko, yaitu risiko produksi, risiko harga, risiko teknologi, risiko tindakan pihak lain serta risiko kecelakaan kerja. Risiko produksi dibidang pertanian lebih besar dibandingkan dengan risiko di sektor non pertanian karena pertanian sangat dipengaruhi oleh alam, seperti cuaca, hama penyakit, suhu, kekeringan, banjir dan segala macam bencana lainnya.
Berbagai risiko yang ada tersebut bisa terjadi pada usahatani padi organik karena teknis usahatani padi organik ternyata berbeda dengan usahatani padi anorganik (Kadarsan, 1992).

Usahatani padi organik merupakan bentuk cara usahatani yang berbeda dengan anorganik. Usahatani padi organik menggunakan input produksi yang berasal dari bahan-bahan organik, sedangkan usahatani padi anorganik menggunakan input produksi yang mengandung bahan kimia. Usahatani padi organik di Desa Rowosari dalam kegiatannya terdapat risiko produksi yang harus dihadapi. Risiko dari sisi produksi terjadi bisa karena adanya gangguan serangan hama dan penyakit tanaman. Hal tersebut bisa terjadi karena penggunaan obat pengendalian hama penyakit tidak lagi memakai pestisida kimia yang relatif lebih cepat membasmi penyakit. Risiko lain yang dapat terjadi bisa disebabkan oleh adanya pencemaran air yang digunakan dalam pengairan tanaman. Budidaya padi organik harus memperhatikan kualitas air yang digunakan, saat pengairan tanaman tidak boleh tercemar oleh bahan kimia. Selain itu dalam pelaksanaan usahatani padi organik petani juga dihadapkan tuntutan budidaya padi organik sesuai dengan standart operasional prosedur dari pihak Lembaga Sertifikasi.

Secara teoritis produksi padi organik yang dihasilkan oleh petani terdapat perbedaan antara petani yang telah lama menerapkan usahatani padi organik dengan petani yang baru menerapkan usahatani padi organik. Produksi padi organik akan meningkat seiring dengan lama waktu usahatani yang telah dilakukan. Disisi lain pelaksanaan usahatani apabila ditinjau dari luas lahan yang diusahatanikan terdapat kecenderungan peningkatan efisiensi biaya apabila semakin luas lahan yang diusahatanikan. Hal hal tersebut menjadi sesuatu yang perlu diteliti terkait dengan risiko yang dihadapi petani dalam usahatani padi organik yang dimulai pada waktu yang berbeda dan berdasarkan luas lahan yang diusahatanikan. 
Penelitian ini bertujuan untuk mengetahui: (1) Besarnya risiko produksi usahatani padi organik secara keseluruhan; (2) Besarnya risiko produksi dilihat dari lama penerapan dan luas lahan pada usahatani padi organik di Desa Rowosari.

\section{KERANGKA PEMIKIRAN TEORITIS}

Menurut Sugiarto (2007), produksi merupakan suatu kegiatan yang mengubah input menjadi output. Kegiatan tersebut dalam ekonomi biasa dinyatakan dalam fungsi produksi. Fungsi produksi menunjukkan jumlah maksimum output yang dapat dihasilkan dari pemakaian sejumlah input dengan menggunakan teknologi tertentu. Sebuah perusahaan dalam melakukan kegiatan produksi dapat dibedakan menjadi dua, yaitu produksi jangka pendek dan jangka panjang. Faktor produksi yang dianggap tetap biasanya seperti mesin, peralatan dan bangunan. Sedangkan faktor produksi yang dianggap dapat berubah (variable input) adalah seperti tenaga kerja, benih, pupuk, obat-obatan dan lainnya.

Produksi menurut Kelana et al. (2000), merupakan suatu usaha atau kegiatan untuk menambah kegunaan (nilai guna) suatu barang. Kegunaan suatu barang akan bertambah bila memberikan manfaat baru atau lebih dari bentuk semula. Proses produksi membutuhkan faktor-faktor produksi yaitu alat atau sarana untuk melakukan proses produksi. Sebagaimana yang telah dikemukakan bahwa faktor-faktor produksi yang dimaksudkan dalam ilmu ekonomi adalah manusia (tenaga kerja), modal (uang atau modal seperti mesin), sumberdaya alam (tanah dan lainnya) serta skill (teknologi). Hubungan teknis antara faktor produksi (input) dengan hasil produksi (output) dijelaskan melalui fungsi produksi.

Hubungan yang dimaksud adalah bahwa produksi hanya bisa dilakukan dengan menggunakan faktor produksi yang dimaksud. Apabila faktor produksi yang akan digunakan tidak ada maka kegiatan produksi juga tidak dapat dilakukan. Produksi yang dihasilkan tanpa menggunakan teknologi, modal, dan manusia disebut produksi alami, yaitu produksi yang dilakukan oleh proses alam. Sedangkan produksi yang dilakukan dengan menggunakan modal, tekonologi dan manusia disebut produksi rekayasa.

Hariyati (2007) mengemukakan bahwa proses produksi seorang produsen mengalokasikan faktor produksi untuk menghasilkan produksi barang. Dalam Proses produksi terdapat dua pertimbangan yang menjadi dasar dalam kegiatan produksi adalah berapa produksi yang harus dihasilkan untuk mencapai keuntungan maksimum dan berapa faktor produksi yang harus digunakan untuk proses produksi tersebut. Pendekatan tradisional pada azas-azas produksi dimulai dengan fungsi produksi. Fungsi produksi adalah hubungan fisik atau hubungan teknis antara jumlah faktor-faktor produksi yang dipakai dengan jumlah produk yang dihasilkan per satuan waktu tanpa memperhatikan harga pada faktor produksi maupun harga produk yang dihasilkan. Oleh karena itu baik produksi maupun faktor produksi mempunyai satuan yang berbeda mendasarkan pada satuan masing-masing faktor produksi maupun produksinya. Hubungan input dengan output dalam produksi digambarkan pada Gambar 1.

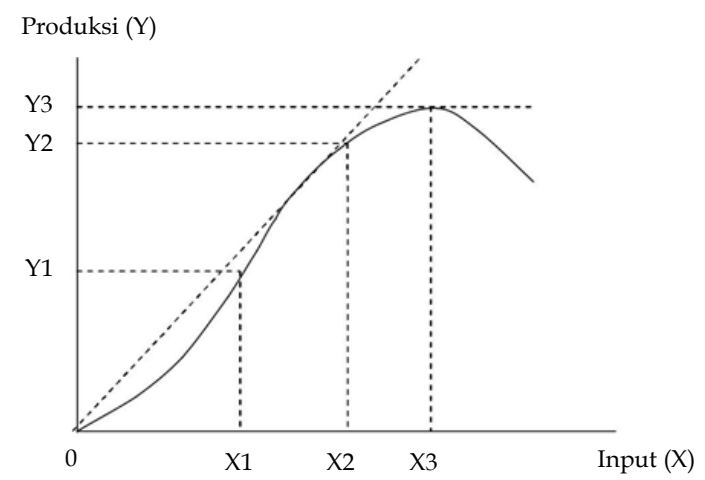

Gambar 1. Hubungan antara Faktor Produksi dan Produk Sumber : Hariyati (2007) 
Jumlah produk yang dihasilkan tergantung dari kuantitas dan kualitas faktorfaktor produksi yang digunakan selama proses produksi. Perusahaan dapat menambah atau mengurangi produk yang dihasilkan itu dengan menambah atau mengurangi jumlah pemakaian satu atau lebih faktor produksi, dengan asumsi kualitas faktor-faktor produksi tersebut tidak berubah. Dengan pemakaian jumlah faktorfaktor produksi yang sama produk yang dihasilkan dapat pula dinaikkan dengan menaikkan kualitas faktor-faktor produksi tersebut.

Hubungan yang terjadi antara input dengan output dalam proses produksi yang umum terjadi adalah dengan meningkatnya faktor produksi variabel akan meningkatkan total produksi sampai suatu titik dimana penggunaan faktor produksi pada kondisi tersebut akan menghasilkan produk yang maksimum. Apabila penggunaan faktor produksi ditambah tidak lagi meningkatkan produk, akan tetapi justru menurunkan produksi. Hubungan yang spesifik yaitu apabila sedikit sekali faktor produksi variabel yang dipergunakan jika dibanding dengan faktor-faktor produksi tetap, terdapatlah kecenderungan terjadinya kenaikan hasil bertambah. Sebaliknya apabila faktor produksi variabel itu sudah banyak jumlahnya dibandingkan dengan faktor-faktor tetap, maka tiap penambahan satu satuan faktor produksi akan mempunyai kecenderungan untuk mengakibatkan kenaikan hasil berkurang. Kenaikan hasil yang meningkat ini terjadi mulai titik nol penggunaan faktor produksi sampai tercapainya titik balik fungsi produksi dan setelah itu kenaikan produksi akan cenderung menurun. Sebagai akibat dari sifat produksi, pada umumnya hubungan antara faktor produksi dan produk pada tiap proses produksi akan cenderung berbentuk kombinasi dari kenaikan hasil bertambah dan kenaikan hasil berkurang. Sifat inilah yang digambarkan dalam satu hukum yang amat terkenal dalam teori produksi, yaitu hukum kenaikan hasil berkurang (Law of Diminishing Return).
Backus et al. (1997) menjelaskan bahwa situasi pengambilan keputusan petani dihadapkan pada dua hal yaitu risiko dan ketidakpastian. Menurut Soekartawi (1994), risiko diartikan sebagai terjadinya kemungkinan merugi atau the possibility of loss, jadi peluang akan terjadinya diketahui terlebih dahulu. Sedang uncertainty adalah sesuatu yang tidak bisa diramalkan sebelumnya, dan karena peluang terjadinya merugi belum diketahui sebelumnya. Risiko dalam produksi pertanian diakibatkan oleh adanya ketergantungan aktivitas pertanian pada alam, diamana pengaruh buruk alam telah banyak mempengaruhi total hasil panen pertanian. Situasi ketidakpastian adalah dimaksudkan kepada adanya risiko berproduksi dalam usahatani pertanian yang dihadapi oleh masing-masing petani dan nampak dari adanya variasi dalam perolehan produksi maupun penerimaannya.

Peristiwa di dunia dapat digolongkan menjadi dua situasi ekstrim, yaitu peristiwa atau kejadian yang mengandung risiko atau risk events dan keadaan ekstrim lainnya adalah kejadian yang tidak pasti atau uncertainty events. Suatu peristiwa lingkungan disebut kejadian berisiko bilamana hasil akhir atau outcomes dan probabilitias terjadinya dapat diketahui. Sebaliknya pada lingkungan ketidakpastian, baik hasil akhir maupun probabilitas terjadinya tidak dapat diketahui. Sementara menurut Haimes (2009), Risiko mengandung pengertian sebagai perubahan kehilangan (change of loss), kemungkinan kehilangan (possibility of loss), selisih antara hasil aktual dari hasil yang diharapkan, atau probabilitas atas hasil yang berbeda dari yang diharapkan. Risiko menunjukkan adanya variasi dari hasil, yang dinyatakan sebagai pengukuran dari peluang dan keparahan

Menurut Retnaningsih (2005), perbedaan pengertian antara risiko dan ketidakpastian belum pernah terdefinisi dengan jelas, bahkan dalam penggunaan praktisnya kedua istilah tersebut cenderung dipakai untuk maksud yang sama. Risiko yang diartikan sebagai suatu kejadian dari kejadian 
yang bersifat tidak pasti atau derajat ketidakpastian yang terjadi pada situasi tertentu, atau secara terminologis dapat diartikan sebagai kemungkinan mengalami kerugian/ kehilangan atau variabilitas kemungkinan kejadian. Hal ini seperti dinyatakan oleh Bond dan Wonder (1980) bahwa pada dasarnya petani menganggap risiko sebagai penyimpangan atau deviasi dari hasil yang diharapkan.

Menurut Darmawi (1994), risiko merupakan penyimpangan hasil aktual dari hasil yang diharapkan. Manajemen risiko merupakan suatu usaha untuk mengetahui, menganalisis serta mengendalikan risiko dalam setiap kegiatan perusahaan dengan tujuan untuk memperoleh efektivitas dan efisiensi yang lebih tinggi.

\section{METODE}

Penelitian ini dilakukan di Desa Rowosari Kecamatan Sumberjambe Kabupaten Jember. Daerah penelitian tersebut dipilih dengan sengaja (purposive method) dengan pertimbangan bahwa Desa Rowosari merupakan desa pertama di Kabupaten Jember yang telah melakukan kegiatan usahatani padi organik sejak tahun 2012. Metode penelitian yang digunakan adalah metode penelitian dekriptif dan analitis.

Metode pengambilan sampel yang digunakan adalah total sampling method. Total sampling adalah teknik pengambilan sampel dimana jumlah sampel sama dengan populasi. Alasan mengambil total sampling karena jumlah populasi kurang dari 100 (Sugiyono, 2008). Sampel yang digunakan adalah lima belas oang petani padi organik di Desa Rowosari Kecamatan Sumbejambe Kabupaten Jember. Metode pengumpulan data yaitu melalui wawancara dan metode dokumentasi. Data yang dibutuhkan dalam penelitian ini adalah data produksi pada tiga kali musim tanam. Risiko Produksi dihitung dengan menggunakan data produksi padi organik pada musim hujan yang dimulai pada bulan Oktober 2016 hingga Bulan Januari 2017, musim kemarau I pada tahun
2017 yang dimulai dari Bulan Februari hingga Mei, dan Musim Kemarau II pada tahun 2017 yang dimulai pada Bulan Juni hingga September. Penelitian dilakukan pada bulan Oktober 2016- September 2017.

\section{ANALISIS DATA}

Besarnya risiko produksi usahatani padi organik di Desa Rowosari dianalisis dengan analisis risiko produksi. Risiko Produksi dihitung dengan menggunakan data produksi padi organik pada musim hujan yang dimulai pada bulan Oktober 2016 hingga Bulan Januari 2017, musim kemarau I pada tahun 2017 yang dimulai dari Bulan Februari hingga Mei, dan Musim Kemarau II pada tahun 2017 yang dimulai pada Bulan Juni hingga September. Sebelum dilakukan analisis, data produksi dikelompokkan menjadi 2 kategori, yaitu : 1) Data produksi berdasarkan luas lahan; 2) Data produksi berdasarkan lama penerapan.

Selanjutnya dilakukan analisis dengan langkah sebagai berikut :

1. Menentukan nilai rata-rata produksi pada 3 musim tanam (musim hujan tahun 2016, musim kemarau I tahun 2017 dan musim kemarau II tahun 2017) dengan rumus sebagai berikut:

Sumber : Hernanto (1995)

$$
E=\frac{\sum_{i=1}^{n} E i}{n}
$$

Keterangan :

$\mathrm{E}=$ Produksi rata-rata GKP $(\mathrm{Kg})$

$\mathrm{Ei}=$ Produksi pada musim tanam ke- $\mathrm{i}(\mathrm{Kg})$

$\mathrm{N}=$ Jumlah musim tanam

2. Menghitung besarnya risiko produksi secara statistik dengan menggunakan ragam dan simpangan baku (standard deviation).

Rumus ragam adalah :

Sumber : Hernanto (1995) 
Rumus simpangan baku merupakan akar dari ragam :

$$
V=\sqrt{v^{2}}
$$

3. Menentukan persentase besarnya risiko terhadap produksi rata-rata yang diperoleh dan batas bawah produksi. Hal ini dilakukan dengan menghitung nilai koefisien variasi $(\mathrm{CV})$ dan batas bawah produksi (L). Rumus koefisien variasi adalah :

Sumber : Hernanto (1995)

$$
C V=\frac{V}{E}
$$

Keterangan :

$\mathrm{CV}=$ Koefisien variasi $(\%)$

$\mathrm{V}=$ Standar deviasi (Simpangan baku) $(\mathrm{Kg})$

$\mathrm{E} \quad=$ Produksi rata-rata GKP $(\mathrm{Kg})$

Batas bawah produksi menunjukkan nilai produksi terendah yang mungkin diperoleh petani. Rumus batas bawah pendapatan adalah :

Sumber : Hernanto (1995)

$$
L=E-2 V
$$

Keterangan :

$\mathrm{L}=$ Batas bawah produksi $(\mathrm{Kg})$

$\mathrm{E}=$ Produksi rata-rata

$\mathrm{V}=$ Standar deviasi (simpangan baku) $(\mathrm{Kg})$

4. Kriteria pengambilan keputusan :

a. Nilai $\mathrm{CV} \leq 0,5$ atau $\mathrm{L} \geq 0$ menyatakan bahwa petani terhindar dari risiko dalam melaksanakan usahatani padi organik.

b. Nilai CV $>0,5$ atau $\mathrm{L}<0$ berarti ada peluang risiko bagi petani dalam melaksanakan usahatani padi organik.

5. Pengujian Hipothesis:

a. Jika nilai CV lahan sempit $(<0,5 \mathrm{Ha})>$ nilai CV lahan sedang $(0,5-2 \mathrm{Ha})>$ nilai $\mathrm{CV}$ lahan luas (> $2 \mathrm{Ha}$ ) maka $\mathrm{H}_{1}$ diterima.

b. Jika nilai CV sertifikasi 2015 (lama penerapan 2 tahun) $>$ nilai $\mathrm{CV}$ sertifikasi 2012 (lama penerapan 5 tahun) maka $\mathrm{H}_{1}$ diterima.

Analisis risiko produksi usahatani padi organik di Desa Rowosari dilakukan dengan melakukan langkah-langkah diatas pada masing-masing sampel yang telah dikelompokkan. Pelaksanaan analisis risiko pada masing-masing kelompok ditujukan untuk mengetahui perkembangan besarnya risiko produksi usahatani padi organik pada lama waktu penerapan yang berbeda dan luas lahan usahatani yang berbeda. Besarnya risiko produksi dapat dilihat pada nilai koefisien variasi $(\mathrm{CV})$ pada masing-masing kelompok.

\section{HASIL DAN PEMBAHASAN}

\section{RISIKO PRODUKSI PADA USAHATANI PADI ORGANIK DI DESA ROWOSARI}

Risiko produksi erat kaitannya dengan produksi yang diperoleh petani dalam usahatani padi organik. Risiko produksi merupakan bentuk besaran penyimpangan produksi aktual yang terjadi dari rata-rata produksi. Berdasarkan adanya berbagai hal yang dapat memicu terjadinya fluktuasi produksi usahatani padi organik, maka perhitungan besarnya risiko produksi perlu dilakukan untuk dapat menentukan tindakan yang tepat dalam menanggulanginya.

Produksi merupakan kegiatan pengalokasian sumberdaya yang dimiliki untuk mendapatkan suatu hasil yang diharapkan. Pada bidang pertanian khususnya pada usahatani, produksi adalah kegiatan mengalokasikan input produksi untuk menghasilkan output. Produksi dalam bidang pertanian dipengaruhi oleh banyak faktor yang dapat dikendalikan ataupun tidak dapat dikendalikan. Faktor yang dapat dikendalikan seperti penggunaan benih, pupuk, obat-obatan, tenaga kerja dan input lainnya, sedangkan hal yang tidak dapat dikendalikan adalah kondisi cuaca dan iklim yang terjadi. Hal tersebut akan berdampak pada tidak menentunya hasil yang diperoleh. Adanya perbedaan atau 
fluktuasi produksi yang terjadi dalam usahatani padi organik disebut dengan risiko produksi.

Hal senada dijelaskan Soekartawi (1993) dimana risiko produksi pertanian diakibatkan oleh adanya ketergantungan aktivitas pertanian pada alam, sehingga berdampak pada adanya variasi dalam perolehan produksi maupun penerimaan. Fluktuasi produksi tiap satu hektar lahan pada tiga musim tanam padi organik dijelaskan pada Tabel 1.

Tabel 1. Produktivitas Usahatani Padi Organik di Desa Rowosari Kecamatan Sumberjambe Kabupaten Jember.

\begin{tabular}{|l|c|}
\hline Musim Tanam & Produktivitas (Kg/Ha) \\
\hline MH 2016 & 4165,37 \\
\hline MK I 2017 & 4956,03 \\
\hline MK II 2017 & 4832,12 \\
\hline Rata-rata & $\mathbf{4 6 5 1 , 1 8}$ \\
\hline
\end{tabular}

Sumber : Data Primer Tahun 2016 (Diolah)

Berdasarkan Tabel 1 dapat diketahui bahwa produktivitas padi per hektar lahan di Desa Rowosari Kecamatan Sumberjambe Kabupaten Jember mengalami fluktuasi atau perbedaan jumlah produktivitas pada tiap musim tanam. Pada musim tanam hujan (OktJan) 2016 rata-rata produktivitas padi organik di Desa Rowosari sebesar 4165,37 Kg/Ha. Sementara rata-rata produktivitas padi organik di Desa Rowosari pada musim kemarau I dan II tahun 2017 berturut-turut sebesar 4956,03 Kg/Ha dan 4832,12 Kg/Ha.

Berdasarkan analisis risiko produksi yang dilakukan terhadap 15 responden di Kelompok Tani Jaya II pada luas lahan 11,90 Ha dengan menggunakan data produksi pada Musim Hujan tahun 2016, Musim kemarau I tahun 2017 dan Musim kemarau II tahun 2017 melalui pengukuran nilai simpangan baku produksi (V) dan nilai koefisien variasi produksi (CV) dihasilkan nilai risiko produksi usahatani padi organik dijelaskan seperti pada Tabel 2.

Berdasarkan Tabel 2, dapat diketahui bahwa nilai risiko produksi pada Kelompok Tani Jaya II sebesar 468,25 Kg atau sebesar $10,1 \%$ dari rata-rata produksinya. Fluktuasi produksi atau besarnya risiko produksi yang dialami oleh petani di adalah sebesar 468,25 $\mathrm{Kg}$ dari rata-rata produksinya, artinya petani dalam melakukan usahatani padi organik dapat mengalami kenaikan ataupun mengalami penurunan produksi sebesar 468,25 Kg dari rata-rata produksi yang diperoleh. Nilai batas bawah produksi (L) merupakan nilai dari selisih antara hasil yang diharapkan dengan dua kali simpangan baku. Berdasarkan perhitungan diperoleh nilai L sebesar 3714,680 , artinya produktivitas terendah yang diterima petani dari hasil usahatani produksi sebesar 3714,680 Kg/Ha.

\begin{tabular}{|c|c|c|c|}
\hline No. & IJk11ran & Keterangan & Ni1 \\
\hline 1 & $\mathrm{~V}$ & Simpangan & 468,25 \\
\hline & & baku $(\mathrm{Kg} / \mathrm{Ha})$ & \\
\hline 2 & $\mathrm{CV}$ & $\begin{array}{l}\text { Koefisien } \\
\text { Variasi (\%) }\end{array}$ & 10,10 \\
\hline 3 & $\mathrm{~L}$ & $\begin{array}{l}\text { Produksi } \\
\text { Terendah } \\
(\mathrm{Kg} / \mathrm{Ha})\end{array}$ & 3714,680 \\
\hline
\end{tabular}

Sumber : Data Primer Tahun 2017 (Diolah)

Perbandingan antara besarnya risiko yang dihadapi dengan produksi rata-rata yang diperoleh adalah sebesar 10,1\% dari produksi rata-rata yang diperoleh, artinya setiap 1 kilogram produksi yang diperoleh terdapat risiko sebesar 0,101 kilogram. Sehingga dalam usahatani padi organik yang dilakukan oleh petani produksi yang diperoleh mengalami fluktuasi atau mengalami kenaikan dan penurunan sebesar 10,1\% dari produksi rata-ratanya.

Melihat nilai risiko produksi yang tidak terlalu besar yaitu $<50 \%$ dan produksi terendah sebesar $3714,680 \mathrm{Kg} / \mathrm{Ha}$, maka dapat disimpulkan bahwa petani pada kelompok tani jaya II masih terhindar dari terjadinya kerugian dalam usahatani padi organik yang dijalankan. Hal ini karena risiko produksi sebesar 10,1\%, sehingga usahatani padi organik yang dilakukan terhindar dari kerugian dalam produksi. 
Jika dibandingkan dengan besar risiko produksi padi organik dari daerah lain, risiko produksi padi organik di Desa Rowosari relatif lebih rendah yaitu sebesa 10,1\%. Sementara menurut penelitian Asbullah (2017) besarnya risiko pada padi organik di Desa Lombok Kulon Bondowoso menunjukkan nilai CV produksi Kelompok Tani Mandiri I dan Mandiri IB masing-masing sebesar $22,83 \%$ dan $19,98 \%$.

\section{RISIKO PRODUKSI BERDASARKAN LUAS LAHAN PADA USAHATANI PADI ORGANIK DI DESA ROWOSARI}

Besarnya risiko produksi yang dihadapi petani dalam usahatani padi organik di Desa Rowosari ternyata disebabkan oleh faktor alam yaitu serangan penyakit kuning dan faktor penggunaan input organik. Sedangkan apabila ditinjau dari segi luas lahan yang diusahatanikan oleh petani, risiko produksi pada usahatani padi organik semakin rendah apabila semakin luas lahan yang diusahatanikan. Hal ini dasarkan pada pengelompokan luas lahan petani yang meliputi lahan sempit (lahan <0,50 Ha), lahan sedang (lahan 0,50 2,00 Ha) dan lahan luas (lahan >2,00 Ha). Berdasarkan analisis risiko produksi yang dilakukan terhadap ketiga luasan lahan tersebut, diperoleh nilai risiko produksi pada Tabel 3

Berdasarkan Tabel 3, dapat diketahui bahwa nilai risiko produksi atau besarnya risiko produksi yang dialami petani pada lahan sempit adalah sebesar 799,48 Kg, pada lahan sedang sebesar $297,04 \mathrm{Kg}$ dan pada lahan luas sebesar $64,73 \mathrm{Kg}$. Hal tersebut menunjukkan bahwa petani dengan lahan sempit dapat mengalami kenaikan dan penurunan produksi sebesar $799,48 \mathrm{Kg}$ dari rata-rata produksinya. Petani dengan lahan sedang dapat mengalami kenaikan dan penurunan produksi sebesar 297,04 Kg dari rata-rata produksinya.

Petani dengan lahan luas dapat mengalami kenaikan dan penurunan produksi sebesar $64,73 \mathrm{Kg}$ dari rata-rata produksinya. Nilai perbandingan risiko terhadap rata-rata produksi yang diperoleh yang ada di lahan sempit milik petani adalah sebesar $17,6 \%$, pada lahan sedang sebesar 6,3\% dan pada lahan luas sebesar 1,3\%. Artinya setiap $1 \mathrm{Kg}$ produksi yang diperoleh petani di lahan sempit memiliki risiko sebesar 0,176 Kg, lahan sedang sebesar $0,063 \mathrm{Kg}$ dan lahan luas sebesar 0,013 Kg. Sementara nilai perbandingan produktivitas terendah (L) pada lahan sempit sebesar $2974,370 \mathrm{Kg} / \mathrm{Ha}$, pada lahan sedang sebesar $4073,212 \mathrm{Kg} / \mathrm{Ha}$, dan pada lahan luas sebesar 4765,915 Kg/Ha. Artinya produktivitas terendah yang diterima petani pada lahan sempit sebesar 2974,370 $\mathrm{Kg} / \mathrm{Ha}$, sementara pada lahan sedang dan lahan luas berturut-turut sebesar 4073,212 $\mathrm{Kg} / \mathrm{Ha}$ dan $4765,915 \mathrm{Kg} / \mathrm{Ha}$.

Berdasarkan perhitungan dapat diketahui bahwa risiko produksi usahatani padi organik cenderung semakin rendah apabila semakin luas lahan yang ditanami padi organik. Hal ini ditunjukkan dengan nilai risiko produksi pada lahan sempit sebesar $17,6 \%$, pada lahan sedang sebesar $6,3 \%$ dan pada lahan luas sebesar $41,3 \%$. Melihat besarnya nilai risiko produksi yang dihadapi oleh petani pada luas lahan sempit, lahan sedang dan lahan luas, maka dapat disimpulkan bahwa petani pada skala lahan tersebut aman dari terjadinya kerugian dalam usahatani padi organik yang dijalankan. Hal ini dikarenakan nilai risiko produksi pada lahan sempit sebesar $17,6 \%$,

Tabel 3. Nilai Risiko Produksi Per Hektar Berdasarkan Luas Lahan Usahatani Padi Organik di Desa Rowosari

\begin{tabular}{|c|l|c|r|r|r|}
\hline No & Luas Lahan & Jumlah & $\begin{array}{c}\text { Nilai Risiko } \\
\text { (Kg) }\end{array}$ & $\begin{array}{c}\text { Nilai Risiko } \\
\text { (\%) }\end{array}$ & $\begin{array}{c}\text { Produktivitas Terendah } \\
\text { (Kg/Ha) }\end{array}$ \\
\hline 1 & Sempit & 5 & 799,48 & 17,6 & 2974,370 \\
\hline 2 & Sedang & 9 & 297,04 & 6,3 & 4073,212 \\
\hline 3 & Luas & 1 & 64,73 & 1,3 & 4765,915 \\
\hline
\end{tabular}

Sumber : Data Primer (2017) 
pada lahan sedang sebesar $6,3 \%$ dan pada lahan luas sebesar 1,3\% adalah kurang dari $50 \%$. Sehingga usahatani padi organik pada ketiga skala usaha tersebut terhindar dari risiko produksi. Petani padi organik di Desa Rowosari masih terhindar dari risiko karena besarnya risiko produksi yang dihadapi tidak lebih dari $50 \%$ dari rata-rata produksinya

Hasil penelitian sesuai dengan penelitian Prihartanti (2014) dimana menunjukkan hasil bahwa semakin tinggi luas lahan yang diusahakan maka semakin rendah risiko yang dihadapi oleh petani. Hal ini didasarkan pada nilai koefisien variasi produksi, petani dengan lahan luas cenderung lebih memperoleh produksi per hektar yang lebih besar dibandingkan petani dengan lahan sempit. Asbullah (2017) melakukan penelitian risiko dengan mengukur besarnya risiko pada padi organik di Desa Lombok Kulon Bondowoso. Hasil penelitian menunjukkan nilai $\mathrm{CV}$ pada lahan sempit sebesar 22,80\%, lahan sedang sebesar 19,76\% dan lahan luas sebesar 11,45\% sehingga dapat dikatakan bahwa semakin luas lahan usahatani padi organik maka risiko produksi semakin rendah, sehingga semakin menguatkan penelitian ini.

Adanya risiko dari segi produksi pada usahatani padi organik merupakan terjadinya penyimpangan produksi yang diperoleh dengan hasil yang diharapkan petani. Besarnya risiko produksi berdasarkan luas lahan usahatani padi organik di Desa Rowosari masih belum merugikan petani, hal tersebut karena terjadinya fluktuasi produksi pada usahatani milik petani terhadap produksi rata-rata yang diperoleh masih dibawah 0,5 atau $50 \%$. Akan tetapi yang perlu diperhatikan adalah terjadinya fluktuasi produksi menunjukkan bahwa petani dalam melakukan usahatani padi organik dapat mengalami kenaikan atau penurunan produksi dari rata-rata produksi yang diperoleh.

\section{RISIKO PRODUKSI BERDASARKAN LAMA PENERAPAN PADA USAHATANI PADI ORGANIK DI DESA ROWOSARI}

Analisis risiko produksi dilakukan dengan menggunakan data produksi pada Musim Hujan tahun 2016, Musim kemarau I tahun 2017 dan Musim kemarau II tahun 2016. Sebelum analisis dilakukan data produksi dikelompokkan berdasarkan Lama waktu penerapan usahatani padi organik. Pengelompokkan dilakukan berdasarkan proses sertifikasi usahatani organik yaitu sertifikasi tahun 2012 dan 2015. Pengelompokan ini ditujukan untuk mengetahui besarnya risiko produksi berdasarkan lama waktu penerapan usahatani padi organik yang berbeda.

Berdasarkan analisis risiko produksi yang dilakukan terhadap responden yaitu lima belas petani padi organik. Dimana terdiri dari tujuh responden pada proses sertifikasi tahun 2012 dengan rata-rata produktivitas sebesar 4426,103 Kg/Ha dan delapan responden pada proses sertifikasi tahun 2015 dengan rata-rata produktivitas 4607,669 $\mathrm{kg} / \mathrm{Ha}$. Nilai tesebut diperoleh dengan menghitung produksi pada Musim Hujan tahun 2016, Musim kemarau I tahun 2017 dan Musim kemarau II tahun 2017 melalui pengukuran nilai simpangan baku (V), nilai koefisien variasi ( $\mathrm{CV}$ ) dan batas bawah pendapatan (L) dihasilkan nilai risiko penerimaan seperti pada Tabel 4.

Berdasarkan Tabel 4, dapat diketahui bahwa nilai risiko produksi rata-rata per hektar yang diperoleh petani dengan proses sertifikasi tahun 2015 pada Musim Hujan

Tabel 4. Nilai Risiko Produktivitas Berdasarkan Lama Penerapan Usahatani Padi Organik di Desa Rowosari

\begin{tabular}{|c|c|c|r|r|r|}
\hline No & $\begin{array}{c}\text { Proses } \\
\text { Sertifikasi }\end{array}$ & $\begin{array}{c}\text { Jumlah } \\
(\mathbf{n})\end{array}$ & $\begin{array}{c}\text { Nilai Risiko } \\
\text { (Kg) }\end{array}$ & $\begin{array}{c}\text { Nilai Risiko } \\
(\mathbf{\%})\end{array}$ & $\begin{array}{c}\text { Produksi Terendah } \\
\text { (Kg/Ha) }\end{array}$ \\
\hline 1 & 2015 & 8 & 572,76 & 12,1 & 3632,187 \\
\hline 2 & 2012 & 7 & 348,80 & 7,8 & 3808,958 \\
\hline
\end{tabular}

Sumber : Data Primer (2017) 
tahun 2016, Musim kemarau I tahun 2017 dan Musim kemarau II tahun 2016 adalah sebesar $572,76 \mathrm{Kg}$ atau $12,1 \%$ dari rata-rata produksinya, sedangkan nilai risiko produksi rata-rata per hektar petani dengan proses sertifikasi pada tahun 2012 adalah sebesar 348,80 Kg atau $7,8 \%$ dari rata-rata produksinya.

Fluktuasi produksi atau besarnya risiko produksi yang dialami oleh petani pada proses sertifikasi 2015 adalah sebesar 572,76 $\mathrm{Kg}$ dari rata-rata produksinya, artinya petani dalam melakukan usahatani padi organik dapat mengalami kenaikan ataupun mengalami penurunan produksi sebesar $572,76 \mathrm{Kg}$ dari rata-rata produksi yang diperoleh. Sedangkan fluktuasi produksi atau besarnya risiko produksi yang dialami oleh petani dengan proses sertifikasi tahun 2012 sebesar $348,80 \mathrm{Kg}$ dari rata-rata produksinya, artinya petani dalam melakukan usahatani padi organik dapat mengalami kenaikan ataupun mengalami penurunan produksi sebesar $348,80 \mathrm{Kg}$ dari rata-rata produksi yang diperoleh.

Perbandingan antara besarnya risiko yang dihadapi dengan produksi rata-rata yang diperoleh pada petani dengan proses sertifikasi tahun 2015 adalah sebesar 12.1\% dari produksi rata-rata yang diperoleh, artinya setiap 1 kilogram produksi yang diperoleh terdapat risiko sebesar 0,12 kilogram. Pada proses sertifikasi tahun 2012 besarnya risiko produksi yang harus dihadapi petani adalah sebesar $7,8 \%$ dari produksi ratarata yang diperoleh, artinya setiap 1 kilogram produksi yang diperoleh terdapat risiko sebesar 0,078 kilogram.

Melihat nilai risiko produksi kedua kelompok petani dengan waktu sertifikasi yang berbeda tidak terlalu besar yaitu $<50 \%$, maka dapat disimpulkan bahwa petani tersebut masih terhindar dari terjadinya kerugian dalam usahatani padi organik yang dijalankan. Kerugian yang disebabkan dari perolehan produksi dapat terjadi apabila nilai besarnya risiko melebihi $50 \%$ dari rata-rata produksi yang diperoleh. Hal ini mungkin terjadi karena apabila semakin besar risiko produksi yang harus dihadapi maka petani juga akan kesulitan dalam memperoleh pendapatan dan mengembalikan biaya-biaya yang dikeluarkan selama proses produksi.

Hasil penelitian menunjukkan bahwa semakin lama penerapan usahatani padi organik maka risiko yang ditanggung akan semakin kecil. Hal ini sesuai dengan hasil penelitian Prayoga (2010) dimana semakin lama penerapan pertanian organik nilai indeks kuantitas input yang semakin menurun. Hal ini mengindikasikan bahwa semakin lama pertanian organik diterapkan maka produktivitas akan semakin meningkat pula. Kondisi ini bisa terjadi karena kondisi kesuburan lahan semakin baik seiring berjalannnya waktu akibat penggunaan pupuk organik.

\section{KESIMPULAN DAN SARAN}

\section{KESIMPULAN}

1. Secara keseluruhan risiko produksi usahatani padi organik di Desa Rowosari sebesar $468,25 \mathrm{Kg}$ atau 10,1\% dari ratarata produksinya. Risiko produksi usahatani padi organik di Desa Rowosari berdasarkan luas lahan pada lahan sempit $(0,5 \mathrm{Ha})$, sedang $(0,5-2 \mathrm{Ha})$ dan luas $(>2$ Ha) berturut-turut sebesar 17,6 \%, 6,3\% dan $1,3 \%$ dari rata-rata produksinya. Semakin luas lahan usahatani padi organik yang diusahakan petani maka risiko produksi akan cenderung semakin rendah.

2. Risiko produksi usahatani padi organik di Desa Rowosari berdasarkan lama penerapan dari tahun 2015 dan 2012 berturut-turut sebesar $12,1 \%$ dan $7,8 \%$ dari rata-rata produksinya. Semakin lama petani menerapkan usahatani padi organik, risiko produksi semakin rendah.

\section{SARAN}

1. Tindakan yang perlu dilakukan oleh petani guna meminimalisir terjadinya risiko produksi adalah dengan melakukan perlindungan tanaman padi organik secara intensif dari serangan hama dan 
penyakit supaya tidak berdampak terhadap penurunan atau fluktuasi produksi terutama pada musim hujan.

2. Usahatani padi organik sebaiknya dilakukan pada lahan sedang $(0,5-2 \mathrm{Ha})$ sampai luas (> $2 \mathrm{Ha}$ ) dimana risiko produksi yang dihadapi petani relatif lebih sedikit dibandingan dengan risiko produksi pada lahan sempit $(<0,5 \mathrm{Ha})$.

\section{DAFTAR PUSTAKA}

Asbullah, Ma'ruf. 2017. Analisis Risiko pada Usahatani Padi Organik di Desa Lombok Kulon Kecamatan Wonosari Kabupaten Bondowoso. Skripsi. Jurusan Sosial Ekonomi Pertanian Universitas Jember.

Bond, G dan Wonder, B. 1980. Risk Attitude among Australian Farmers. Australian Journal Agricultural Economics, 24 (1) : 16-34.

Darmawi, Herman. 1994. Manajemen Risiko. Jakarta : Bumi Aksara.

Haimes YY. 2009. Risk Modeling. Assesment, and Management. John Willey and Sons Inc.

Hakim, Maryati. Alamsyah, Idham. Dwi. 2014. Perbandingan Tingkat Produktivitas dan Pendapatan Petani Padi Pengguna Pupuk Organik pada Agroekosistem Lahan yang Berbeda di Sumatera Selatan. Prosiding Seminar Nasional Lahan Suboptimal.

Hanson, James; Robert, Dismukes; William, Chambers; Catherine, Greenec and Amy Kremend, 2014, Risk and Risk Management in Organik Agriculture :Views of Organik Farmers, Renewable Agriculture and Food Systems., Department of Agricultural and Resource Economics : The University of Maryland, College Park.

Hariyati, Yuli, 2007, Ekonomi Mikro (Pendekatan Matematis dan Grafis). Jember : CSS.

Hernanto, Fadholi, 1995, Ilmu Usahatani. Jakarta, Penebar Swadaya.
Kadarsan, Halimah. W, 1992, Keuangan Pertanian dan Pembiayaan Perusahaan Agribisnis, Jakarta : PT Gramedia Pustaka Utama.

Kelana, Sudjana, Brastoro, Herlambang dan Sugiarto. 2000. Ekonomi Mikro Sebuah Kajian Komprehensif. Jakarta : PT Gramedia Pustaka Utama.

Mubyarto, 1994, Pengantar Ekonomi Pertanian, Jakarta, LP3ES.

Prayoga, Adi, 2010, Produktivitas dan Efisiensi Teknis Usahatani Padi Organik Lahan Sawah. Agro Ekonomi 28 (1): 11.

Prihtanti, 2014, Analisis Risiko Berbagai Luas Penguasaan Lahan pada Usahatani Padi Organik dan Konvensional, AGRIC 26 (1): 34-35.

Retnaningsih, Nugraheni, 2005, Perilaku Petani dalam Menghadapi Risiko pada Usahatani Bawang Putih di Kecamatan Tawangmangu, Jurnal EKSAKTA, 16 (1) :61-68.

Ricky, Layla Ulfah, 2012, Petani di Desa Koto Lebu, Kerinci : Dari Revolusi Hijau Menjadi Petani Organik,Skripsi, Jurusan Antropologi Fakultas Ilmu Sosial dan Ilmu Politik Universitas Andalas Padang.

Saptana dan Ashari, 2007, Pembangunan Pertanian Berkelanjutan Melalui Kemitraan Usaha. Jurnal Litbang Pertanian 26 (4): 123-124.

Soekartawi., Rusmadi., dan Damaijati, 1993, Risiko dan Ketidakpastian dalam Agribisnis, Jakarta : PT Raja Grafindo Persada.

Sudrajat, O, 1994, Pembangunan di Indonesia. Jakarta, Universitas Terbuka

Sugiarto, Herlambang, Brastoro, Sudjana dan Kelana, 2007. Ekonomi Mikro (Sebuah Kajian Komprehensif). Jakarta : PT Gramedia Pustaka Utama.

Sugiyono, 2008, Metode Penelitian Pendidikan dengan Pendekatan Kuantitatif, Kualitatif, dan R\&D. Bandung : Alfabeta. 
